\title{
Editorial
}

\section{"Modern Problems of Aquatic Ecology", 4th International Scientific Conference to commemorate Professor G.G. Winberg, 11-15 October 2010, St. Petersburg, Russia}

This international conference was chaired by Professor Alexander F. Alimov (Alimov, 2003), organized by the Zoological Institute of the Russian Academy of Sciences (RAS), together with the St. Petersburg Scientific Centre of the RAS, the Russian Hydrobiological Society at RAS and Scientific Council of Hydrobiology and Ichthyology of the RAS, to commemorate the 105th anniversary of Professor Georgii Georgievich Winberg (1905-1987) - Ozernyuk (2005).

Professor Winberg was the founder of the Russian School of Biological Productivity Studies, a leading scientific school in the former USSR, with international acclaim and leadership in the aquatic ecosystems of the International Biological Programme. In 1972, he was the scientific chair and one of the organizers of the SIL Congress in Leningrad (now St. Petersburg). In 1977, SIL awarded the Naumann-Thienemann Medal to Prof. Winberg, the highest honor that can be bestowed internationally for outstanding scientific contributions to limnology. Till the end of his life Prof. Winberg was the Head of the Laboratory of Freshwater and Experimental Hydrobiology at the Zoological Institute of the Russian Academy of Sciences and President of the All-Union Hydrobiological Society (now the Russian Hydrobiological Society).

The aim of the conference was to discuss fundamental ideas in aquatic ecology that have evolved from the basic biological knowledge developed by Winberg and his contemporaries. This special issue brings together some of the highlights of this conference.

Three papers illustrate the first two themes on 'Matter cycling and energy flows in aquatic ecosystems' and 'Ecological physiology of aquatic organism', Krevs and Kucinskiene on oxygen and sulfur metabolism and their associated microbes in stratified lakes; Ji, Berezina, Golubkov et al. showing the fundamental dependence of individual phosphorus excretion rate on individual dry mass for benthic macroinvertebrates; Demars et al. showing the role of temperature and hydraulics on the balance of stream metabolism in subarctic Icelandic geothermal streams, providing additional fundamental science to the Ural Branch of the Russian Academy of Science (Bogolitsyn and Bolotov, 2011).

The 'Structure and functioning of aquatic ecosystems in changing environment' is illustrated with papers by Zawisza and Szeroczyńska pioneering the understanding of Cladocera distribution in the Spitsbergen to establish baseline information for paleo-limnological studies; and Szeroczyńska and Zawisza paleolimnological study suggesting increase in eutrophication from the examination of subfossil Cladocera and Pediastrum remains in two Finnish Lobelia lakes.

Within 'Populations, communities of aquatic organisms and food webs', Verbitsky and Verbitskaya presented a novel experiment based on a solid replicated before and after control impact experiment with recovery period to study the effect of temperature step changes on Cladocera population dynamics; Čiamporová-Zaovičová and Čiampor reported on aquatic beetles of the alpine lakes and ponds of the Tatra Mountains: diversity, ecology and small-scale population genetics.

Many papers were presented on 'Environmental state and health of aquatic ecosystems', illustrated here with long term monitoring of human impacts by Nikulina and Gubelit on the cyanobacteria and macroalgae of the Neva estuary (St. Peterburg) and by Deksne on the zooplankton communities of the River Daugava (Belarus and Latvia); and experimental work 
by Lenzi and Renzi to study the possible remediation of a eutrophic Italian coastal lagoon by sediment disturbance.

Finally the 'Significance of invasive species in aquatic ecosystems' is represented by the compelling study of Arbačiauskas, Višinskienè and Smilgevičienè showing that current ecological quality assessment by existing indices may be affected by non-indigenous invading species in Lithuania

\section{REFERENCES}

Alimov A.F., 2003. Towards a theory of the functioning of aquatic ecosystems, Backhuys Publishers, Leiden.

Bogolitsyn K.G. and Bolotov I.N. (eds.), 2011. Functioning of subarctic hydrothermal ecosystem in the winter period, Ural Branch of the Russian Academy of Sciences (UB RAS), Ekaterinburg (in Russian).

Ozernyuk N.D., 2005. G.G. Winberg (1905-1987). Biol. Bull., 32, 530-531.

N.A. Berezina and S.M. Golubkov, Zoological Institute, Russian Academy of Science, 199034 St. Petersburg, Russia

B.O.L. Demars, The James Hutton Institute, Craigiebuckler, Aberdeen AB15 8QH, Scotland, UK

A. Razinkovas Coastal Research and Planning Institute, Klaipeda University, Klaipeda 92294, Lithuania 